\title{
THE ROLE AND IMPORTANCE OF PROMOTION IN THE DEVELOPMENT OF GASTRONOMIC TOURISM OF THE REPUBLIC OF CROATIA
}

\author{
Ivica Batinić \\ Vocational school, Vukovar, Croatia \\ ivica.batinic@email.t-com.hr
}

Professional Paper

doi:10.5937/jouproman5-14549

\begin{abstract}
Gastronomic travel is all the more popular all over the world, and gastronomic tourism has become a selective form of tourism aimed at creating a top tourist experience. Republic of Croatia is proud of its rich gastronomy in such a small area of outstanding cultural specificity and diversity, and with an interesting gastronomic offer tourists can be provided with completely different and new experiences. With a rich, attractive and autochthonous gastronomic offer that will have segments of new experiences and adventures as well as quality cooperation between state (development) institutions and tourist entities in tourist destinations, the Republic of Croatia can successfully develop and promote gastronomic tourism and become a recognizable world gastronomic destination on the demanding Tourism market.
\end{abstract}

Keywords: Croatia, gastronomy, tourism, promotion, development.

\section{INTRODUCTION}

Croatia is a tourist destination that builds its identity on a demanding tourist market with a variety of natural resources, and rich historical and cultural heritage. Croatia has become a country that has managed to elevate itself to a global tourist level and position itself as one of the most desirable tourist countries in Europe and the world. Increased tourism development and changes in guest demand create new forms of tourism to meet all the wishes and needs of tourist consumers. Croatia is a country that has tremendous opportunities to develop more selective forms of tourism, and one of them is gastronomic tourism.

\section{TERMS GASTRONOMY AND GASTRONOMIC TOURISM}

'Gastronomy (from Greek gaster = stomach + nomos $=$ rule, order) is the cooking skill; the skill of preparing good meals; cult of selected food and cooking craft. '(Klaić, B.1990).' 'Gastronomy encompasses all that concerns with cooking and culinary skills, in the wider sense it includes gourmets and gastrologists, and in the widest sense the link between culture and food, or the art of eating, culinary art.' (Drpić, K., Vukman, M. 2014). For modern consumer-tourists, it is more and more frequent to visit tourist destinations that, apart from passive vacations, also offer the possibility of active participation in attractive gastronomic events and the traditional way of making indigenous gastronomic specialties. 'Gastronomy is closely related to tourism, it completes the experience of the destination, and the best catering facilities are those that offer local dishes, as gourmets and ordinary guests love to taste new dishes that they have not yet eaten.' (Richards, G. 2012). 
Gastronomic travel is all the more popular in Europe and the world, and gastronomic tourism has become a selective form of tourism aimed at creating a top tourist "gastro" experience. 'Gastronomic tourism entails a visit to a destination whose primary goal is to satisfy the interests of local or national gastronomy, including consuming food and beverages, learning to prepare meals, buying domestic products and attending cooking classes' (Smith, M., Macleod, N., Hart Robertson, M. 2010).

\section{BASIC CHARACTERISTICS OF CROATIAN GASTRONOMY}

Croatia's gastronomy highlights the differences and specifics that have arisen from historical events and the remains of different European cultures, traditions and customs. 'Continental cuisine is characterized by earlier Slavic roots and newer contacts with more familiar gastronomic representatives - Hungarian, Viennese and Turkish cuisine, while the Adriatic cuisine is characterized by the influence of the Greeks, Romans and Illyrians, as well as the later Mediterranean cuisine - both Italian and French.' (Ratkajec, S. 2006). 'Different natural and economic conditions and cultural influences have led to the development of three major areas that have been divided due to their specialties, namely the areas of northern and central Croatia, mountainous Croatia and Lika and coastal Croatia. In the area of northern and central Croatia, whose parts are the golden Međimurje, Podravina, Hrvatsko Zagorje and Slavonia, the common properties of the diet are the use of pig fat, pumpkin seed oil, pork as the basis of meat nutrition and plenty of milk and dairy products such as sour milk, cream and fresh cheese. Meat is of great importance in the area of central Croatia where it is mostly processed into cured meat products such as sausages, bacon, ham, greaves or famous Slavonian kulen. Stews (čušpajz), dishes with sauerkraut or beet in different combinations or shepherd's stew (čobanac), the famous stew of several kinds of meat, potatoes and dumplings are also ancient dishes that are still prepared in many households, and their taste is of interest to tourists. Štrukli, type of strudel with filling, is the most popular dish in this area. They can be salted or sweet, cooked or baked, or in soups, with cheese, apple, pumpkin, poppy, millet, etc. They use to prepare meals of buckwheat, millet or barley porridge, and these foods are all the more frequently finding their way onto a contemporary menu. The cuisine of the Croatian mountainous region, Lika and Gorski Kotar, shows special cultural specificities. Today, the meat is still being prepared with beans, sour pickles or beet, grilled or baked, dried in the smoke. Most common side dish to meat are the potatoes, in Lika called "pole". Wild game dishes are also very famous, especially stews of venison or boar. They are eaten with different types of mushrooms that abound in the local forests. The cuisine of these, traditionally livestock areas, is also rich in dairy products, such as the famous Lika "škripavac" cheese and "basa", a specialty made from layers of salted fresh and unsalted cooked milk. The Adriatic coast and the entire Mediterranean part, the coastal Croatia, is a Mediterranean cuisine area. The main features of this cuisine are the use of olive oil and fish and seafood based dishes. From these, the most famous dishes of Dalmatia, "buzara" and fish stews, are prepared from several species of fish and seafood in one pot, until the fish is baked on the grill or under the bell. 
Consumed is a lot of vegetables, herbs, as well as self-propagating herbs such as wild asparagus and herbaceous plants. The favorite beef dish is a stew called "pašticada", which is prepared by baking with the addition of herbs, dried plums and figs, bacon and black wine, and most often with a side dish of gnocchi, potato dumplings. Pork is smoked and dry cured to make prosciutto and pancetta in the open. Among the cheeses is the most famous one is the dry sheep's cheese from the Pag island. In the Adriatic, there is a well known tendency towards toasted bread, the baškot, paškot, baškotin, which in the distant past use to replace bread for fisherman and sailors during their long stays on the sea.' (Randić, M., Rittig Beljak, N. 2006).

Gastronomy is part of the tradition of Croatian regions and an important factor of their contemporary identity. It is an integral part of the tourist offer of various gastronomic events, restaurants, hotels, peasant tourist farms that offer traditionally prepared dishes or those based on tradition.

\section{THE ROLE AND IMPORTANCE OF PROMOTION IN THE DEVELOPMENT OF \\ GASTRONOMIC TOURISM OF THE REPUBLIC OF CROATIA}

The development of gastronomic tourism in a particular destination affects the placement of domestic products, the enrichment of the total tourist offer and the promotion of the unique image of the destination at an international level. For the development of gastronomic tourism at the state and local level, a very important role is played by promotional activities that can successfully bring the indigenous Croatian gastronomy to current and potential guests (tourists). 'Promotion in tourism encompasses activities aimed at attracting tourists/customers to a particular area (country) and encouraging the purchase of certain products and services at the place of stay and during the travel.' (Kobašić, A., Senečić J. 1989). State institutions (Ministry of Tourism, Croatian National Tourist Board) and various tourist and hospitality companies at tourist destinations (local tourism, hotels, restaurants, tourist agencies, etc.) must be obliged to take part in the promotion of gastronomic offer. Basic and necessary promotional activities are:

1. Gastronomic events / festivals. Croatian National Tourist Board and the Ministry of Tourism must organize a large number of attractive gastronomic events / festivals at the international, national and local level in cooperation with various tourist entities at tourist destinations. 'A big role in this process is played by restaurants and top chefs, and national restaurants and other catering facilities that must be key figures in organizing special events, gastro festivals or promoting gastro-guides at home and abroad.' (Gaztelumendi,I. 2012).

2. Thematic "gastro" roads. Croatia is successfully developing at various tourist destinations themed "gastro" roads (sardine road, cheese road, olive oil road, honey road) that must be continually promoted in the country and abroad.

3. Gastronomic maps / guides. State institutions and various development stakeholders must produce quality gastronomic maps/guides for tourists at the state and local level. 'Specialties and varieties, national and regional dishes and traditional cuisine should be noticeable on this map.' (Ruzic, P. 2009). 
4. Menus. Restaurants and hotels at tourist destinations must create special menus and daily menus with indigenous Croatian specialties. Special menus and daily menus can be a very important means of promoting local and national gastronomy.

5. Education. Restaurants and hotels at tourist destinations must additionally educate chefs and waiters in indigenous Croatian gastronomy. Chefs and waiters must become top gastronomes because quality and professional staff can successfully promote gastronomy of a destinations as well as Croatian gastronomy as a whole. 'There are many skills that a gastronome has to overcome: knowledge of the cuisine, bar and restaurant from the recipe and offer point of view, and technical point of view, knowledge of famous wines, the procurement system, the quality system, must have good organizational abilities, knowledge of personnel solutions in the restaurant or hotel, knowledge of the household, have a personality, knowledge of the history and geography, foreign languages and must have a high level of personal culture and behavior and a way of dressing that must point to seriousness and communicative nature.' (Marović, M.2016).

6. Web pages. Many tourist entities at tourist destinations can promote autochthonous gastronomic specialties from their own offer and Croatian gastronomy as a whole through their own websites. 'In addition to oral recommendations and the transfer of experience, the inevitable places of exchange of information, criticism and praise are web pages, forums and social networks.' (Sharples, L., Mitchell, R.,
Macionis, N., Cambourne, B., Mitchell, R., Johnson, G. 2000.)

\section{CONCLUSION}

Croatian tourism has all the potential for the development of modern and attractive gastronomy as a unique form of selective tourism, i.e. tourists can attract Croatian tourist destinations with an interesting, rich and indigenous gastronomic offer that will have segments of new "gastro" experiences and adventures. The development and promotion of gastronomic tourism must include top-quality and attractive gastronomic events, a number of themed "gastro roads", special menus with autochthonous Croatian specialties and exceptionally high quality and professional staff in catering facilities. In addition to natural resources and a rich cultural and historical heritage, gastronomy can be imposed in the future as a comparative advantage on which we can build the future development of tourism. With the development of gastronomy, the consumption by guests (tourists) would increase, new jobs would be opened and the entire tourist offer of destinations would be enriched.

\section{REFERENCES}

[1] Klaić,B. (1990).Rječnik stranih riječi, Zagreb, Nakladni zavod Matice Hrvatske.

[2] Drpić, K., Vukman, M. (2014). Gastronomija kao važan dio turističke ponude u Hrvatskoj, Praktični menadžment, Virovitica, Visoka škola za menadžment u turizmu i informatici. 
[3] Richards ,G. (2012). An overwiew of food and tourism trends and policies in OECD, Food and Tourism Experience, The OECD - Korea Workshop, OECD Publishing.

[4] Smith, M., Macleod, N., Hart Robertson, M., (2010).Key Concepts in Tourist Studies, London, SAGE.

[5] Ratkajec,S.(2006). Ugostiteljstvo, Zagreb, Školska knjiga.

[6] Randić, M., Rittig Beljak, N. (2006). Svijet hrane u Hrvatskoj, Zagreb, Etnografski muzej.

[7] Kobašić,A., Senečić J.(1989). Marketing u turizmu, Zagreb, Školska knjiga.

[8] Gaztelumendi, I. (2012). Global trend in food tourism, Madrid, UNWTO Publishing.

[9] Ružić,P.(2009) .Ruralni turizam, Poreč, Institut za poljoprivredu i turizam.

[10]Marović, M. (2016). Razvoj studija gastronomije u svijetu i Hrvatskoj, Šibenik, Veleučilište u Šibeniku.

[11] Sharples, L., Mitchell, R., Macionis, N. and Cambourne, B. with Mitchell, R. and Johnson, G.: (2000). Wine Tourism Around the World, ButterworthHeinemann, Oxford. 